\title{
Characterization and Origin of the Miocene Mudawwara-Quwayra Basaltic Dike, Southern Jordan
}

\author{
Hani Alnawafleh ${ }^{1,2^{*}}$, Khaled Tarawneh ${ }^{1}$, Khalil Ibrahim ${ }^{3}$, Khitam Zghoul ${ }^{3}$, Awad Titi ${ }^{1}$, \\ Rami Rawashdeh ${ }^{1}$, Khaled Moumani ${ }^{4}$, Ahmad Masri' ${ }^{4}$ \\ ${ }^{1}$ Faculty of Engineering, Al-Hussein Bin Talal University, Ma'an, Jordan \\ ${ }^{2}$ Faculty of Engineering, Tafila Technical University, Tafila, Jordan \\ ${ }^{3}$ Faculty of Natural Resources and Environment, Hashemite University, Zarqa, Jordan \\ ${ }^{4}$ Geological Mapping Division, Geology Directorate, Natural Resources Authority, Amman, Jordan \\ Email: " hanialnawafleh@ahu.edu.j, ’hani1995@yahoo.com
}

Received 28 June 2015; accepted 22 August 2015; published 25 August 2015

Copyright (C) 2015 by authors and Scientific Research Publishing Inc.

This work is licensed under the Creative Commons Attribution International License (CC BY).

http://creativecommons.org/licenses/by/4.0/

(c) (i) Open Access

\section{Abstract}

Petrographic, mineralogical and geochemical investigations were carried out on representative samples from the Mudawwara-Quwayra Dike (MQD) in southern Jordan. The MQD intruded Paleozoic and Cretaceous rocks as sub-vertical basaltic plugs, striking NW-SE along a fault zone and extending for more than $100 \mathrm{~km}$. The MQD forms irregularly positive features, and is represented by symmetrical, elliptical, elongated or circular hills. It comprises thin basaltic layers intercalated with pyroclastics and inclusions of different size and lithology, including limestone, sandstone, phosphate, quartzite, and marble. Petrographically, the rock exhibits phyric, porphyritic, vitrophyric and locally glomerophyritic textures manifested by plagioclase, clinopyroxene and rare olivine and set in a matrix of plagioclase, pyroxene, brown glass and opaque phases. Clinopyroxene and olivine phenocyrsts show disequilibrium textures such as reaction/resorbed rims in the forms of corroded ends. The paragenetic sequence shows that olivine is the first phase to be crystallized and coexisting with pyroxene at sometime, while pyroxene continues crystallization. Plagioclase might have crystallized in contemporaneous later than the pyroxene. The MQD rocks are classified as basalt and exhibit a narrow range of silica with a unique subalkaline affinity. This is most probably attributed to assimilation of the abundant siliciclastic inclusions by the ascending magma. Emplacement of the MQD is attributed to regional phase of magmatism in Jordan and Saudi Arabia, which is probably the peripheral extension of a large magmatic event widely exposed in the Red Sea realm.

"Corresponding author.

How to cite this paper: Alnawafleh, H., Tarawneh, K., Ibrahim, K., Zghoul, K., Titi, A., Rawashdeh, R., Moumani, K. and Masri, A. (2015) Characterization and Origin of the Miocene Mudawwara-Quwayra Basaltic Dike, Southern Jordan. International Journal of Geosciences, 6, 869-881. http://dx.doi.org/10.4236/ijg.2015.68071 


\section{Keywords}

\section{Jordan, Basalt, Dike, Miocene, Geochemistry}

\section{Introduction}

Neogene-Quaternary volcanic rocks are mainly widespread in the northwestern part of the Arabian Plate including Jordan (Figure 1(A)). The petrogenesis and magma source regions in northern Arabia have been reviewed and discussed in the work of Krienitz et al. (2013). Basaltic rocks in Jordan are distributed in many localities, including northern, northeastern, central and southern parts of the country (Figure 1(B)). Early Miocene basaltic activity in the form of NW-SE dikes is known from northeast, central and southern Jordan [1]-[4]. MudawwaraQuwayra dike (MQD) is the most important NW-SE dike in southern Jordan. The regional trend of the dike is parallel to the Red Sea axis [3] [5]-[13]. The basaltic magmatic activities are common in neighboring countries (e.g. [14] [15]). In southwestern Sinai, they are commonly in the form of basaltic dykes. The trend of these dykes is quite similar to that of the studied area which reflects the influence of pre-existing tectonic structures in the area [15].

The K-Ar dating results of the MQD gave an age of $20 \pm 0.23 \mathrm{Ma}$ and were considered to be of Mio-Pliocene age [16]. Three activity phases were determined for the NW-SE Qitar El Abed dike, which occurred in NE Jordan, starting from the oldest (around $23 \mathrm{Ma}$ ) to the youngest at around 1.7 Ma [3] [11] [17]. Ages in the range between $24 \mathrm{Ma}$ and $19 \mathrm{Ma}$ were obtained from dikes occurring in central Sinai [18] and in northeast Jordan [11]. These dating results suggest that a regional phase of magmatism has been active in the study area during the early Miocene. This is in agreement with the time attributed to the opening of the Red Sea by Hempton [19], Ilani et al. [11], and Tarawneh et al. [3].

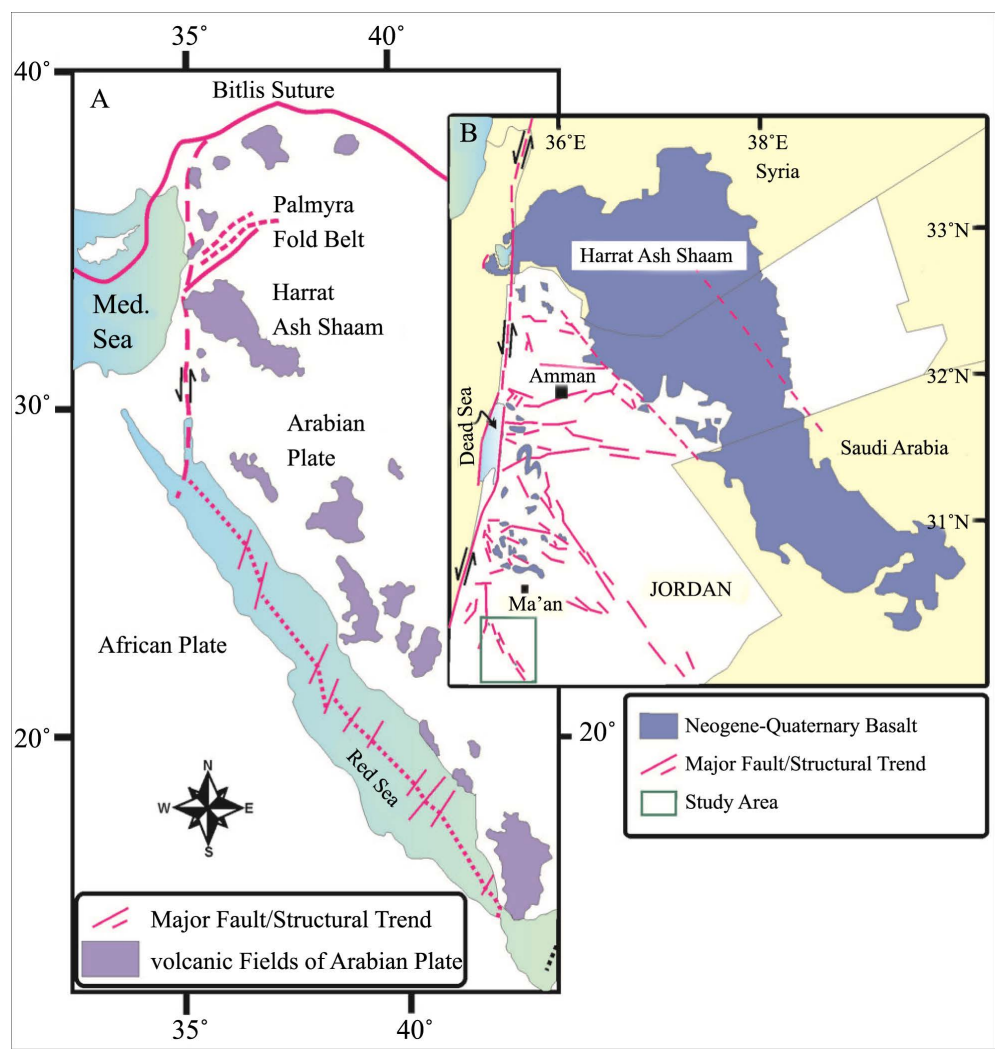

Figure 1. Map of the Miocene-Recent intraplate volcanic field in Jordan along the eastern margin of the Dead Sea plate boundary. 
Previous studies regarding the volcanic activity related to the MQD are scarce. It is the purpose of this study to provide a detailed description of the mineralogy, petrology and geochemistry of the MQD and its associated sedimentary inclusions, and to compare the MQD with the approximately synchronous Miocene volcanic rocks of the region. The new data allow a better understanding of the volcano-tectonic history of southern Jordan and the northern Arabian Plate.

\section{Geological Setting}

The study area is located in south Jordan about $50 \mathrm{~km}$ south of the city of Ma'an (Figure 1(B)). The MQD discharged from swarms of fissures associated with NW-SE Mudawwara-Quwayra Fault System (Figure 2). It can be traced on the aerial photos and satellite images crosscutting the region from Mudawwara in the southeast at the Saudi Arabia borders to Quwayra area in the northwest with a total length of up to $100 \mathrm{~km}$. This regional fault and the associated MQD are truncated by the N-S strike-slip Quwayra Fault [20].

\section{Sampling and Methodology}

More than forty representative samples were collected from different parts of the MQD for petrographic, mineralogical and chemical analyses. Fifty thin sections were prepared and petrographically investigated via polarizing microscope type Lica with different magnifications. Major, minor and trace elements were analyzed on representative samples using multi-channel XRF spectrometry by fused glass disks at the Natural Resources Authority of Jordan. For this aim rock powders were dried for two hours at $110^{\circ} \mathrm{C}$ and ignited in an electric furnace at $1000^{\circ} \mathrm{C}$ for one hour. Ignited samples were then mixed with sodium tetraborate (1:7) and fused in Pt crucibles

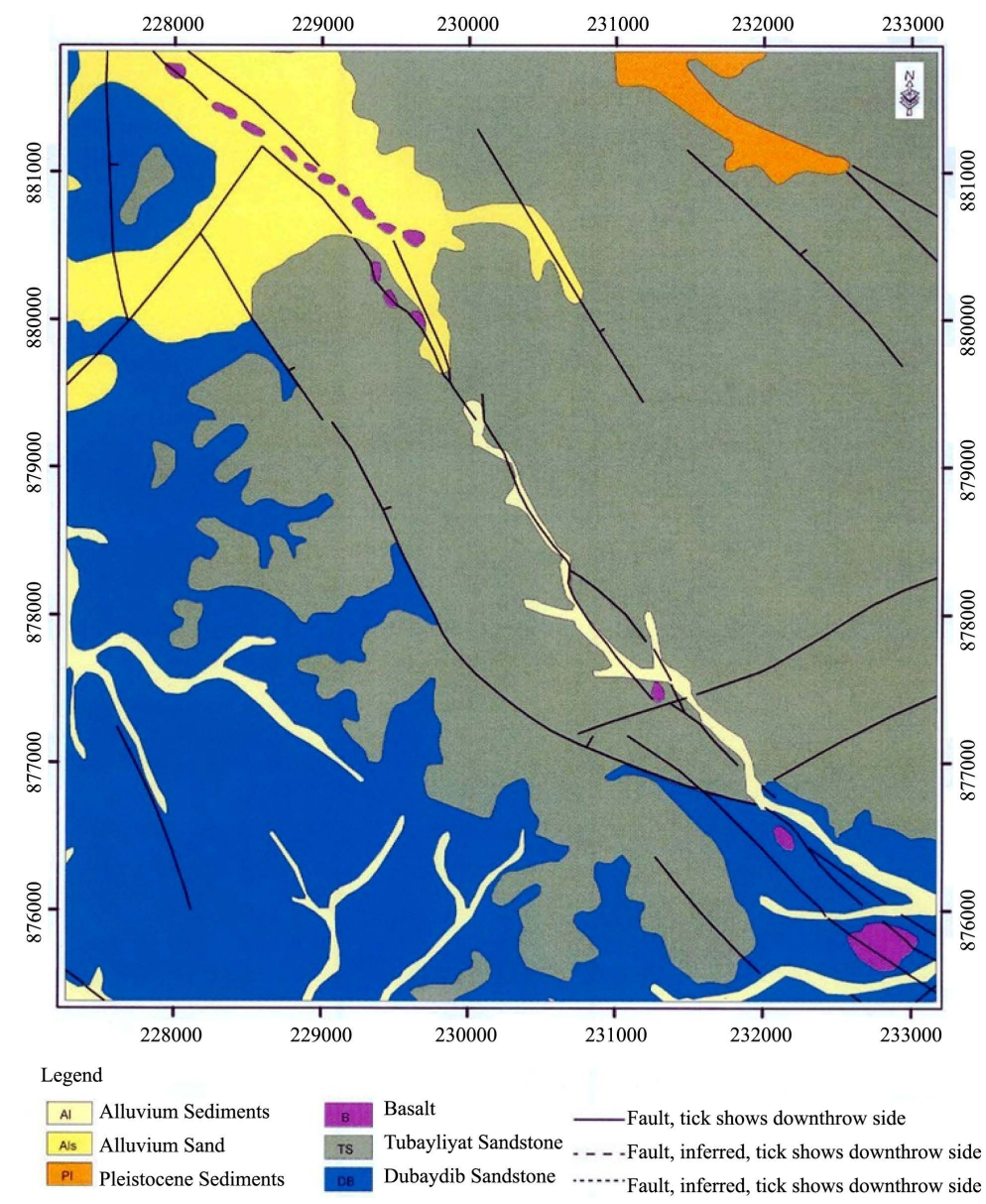

Figure 2. Geological map showing the QMD, modified after Abu Lihie (1988). 
over gas burners for one hour. Melts were poured into a Pt mold creating $32 \mathrm{~mm}$ diameter glass disks. $\mathrm{Na}_{2} \mathrm{O}$ was determined by atomic absorption spectrometry (AAS), where dried samples were treated with HF acid, evaporated, and then dissolved in $\mathrm{HCl}-\mathrm{KCl}$ solution. Trace elements were analyzed by inductively coupled plasmamass spectrometry (ICP-MS) following a combined lithium metaborate fusion, multiacid dissolution technique.

\section{Result and Discussion}

\subsection{Field Relation}

The dike forms positive irregularly features and represented by a symmetrical, elliptical, elongated or circular plugs, domes and hills that varies in their sizes (Figure 3). The maximum dimensions of individual features are $20 \mathrm{~m}$ in height, $150 \mathrm{~m}$ in length and up to $100 \mathrm{~m}$ wide (Figure 3). A considerable variation in these dimensions is recorded (Table 1). Such variation probably corresponded with the tectonic regime of the area [14].

Field investigations of the MQD indicate presence of thin basaltic flows intercalated sometimes with pyroclastic material. Highly weathered basaltic bombs and crustal inclusions are common. Some parts of MQD plugs have no obvious chilled margin, whereas the wider parts of the MQD have more than $10 \mathrm{~m}$ macroscopic pale grey in color chilled zone. The basaltic rocks in the study area are variable in thickness and weathering character istics from dense to vesicular basalt. Dense basalt is with smooth surface, showing black to brown and greenish color. The basalt boulders range in size from $0.5 \mathrm{~m}$ to $3 \mathrm{~m}$ with irregular shape. Vesicles are cylindrical, elon-
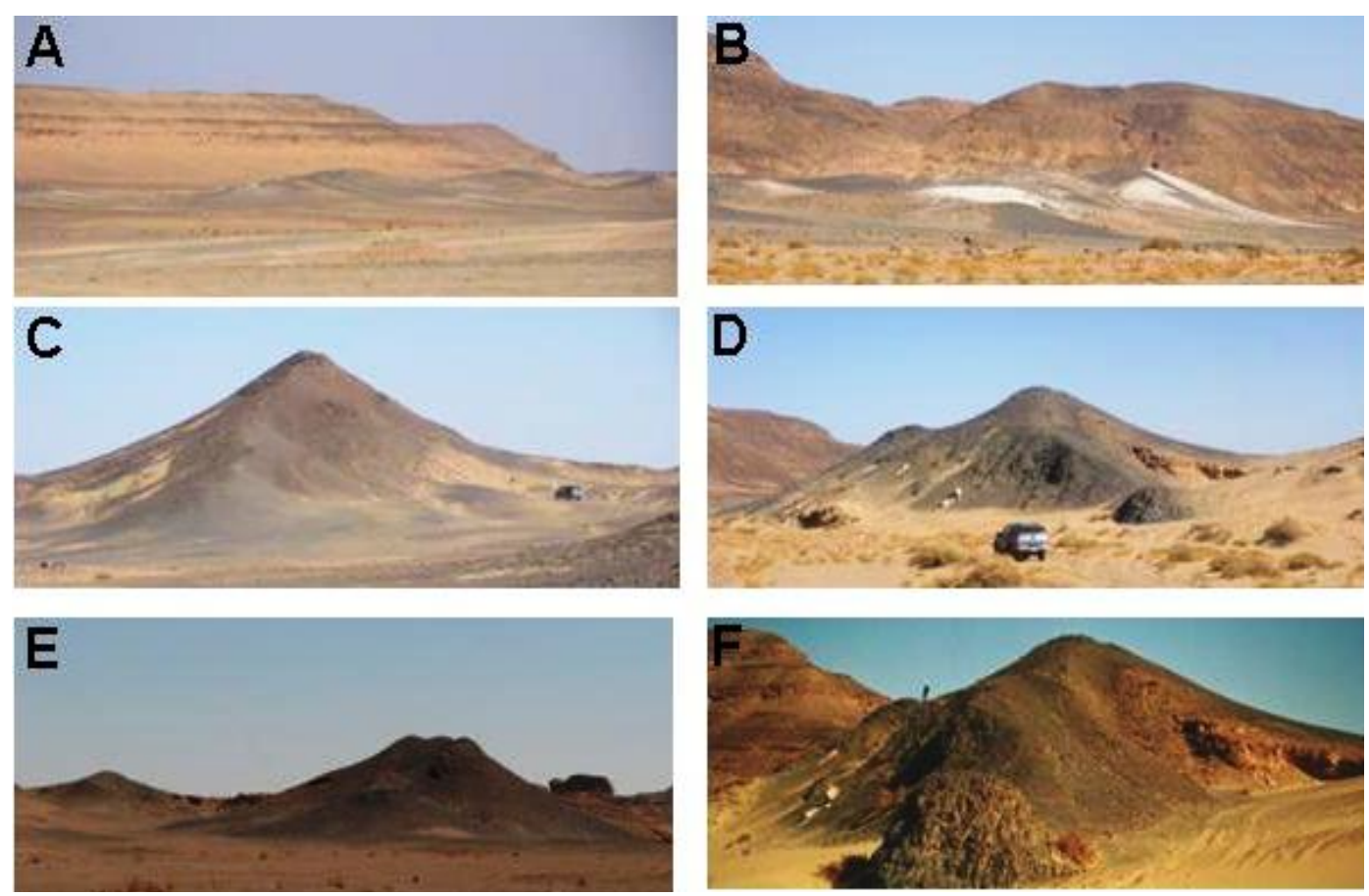

Figure 3. Selected outcrops of the MQD showing various morphologic features. [A-B] dike forms positive irregularly features and represented by a symmetrical, elliptical, elongated or circular plugs. [C-F] The MQD intruded Paleozoic and Cretaceous rocks as sub-vertical basaltic plugs, striking NW-SE along a fault zone.

Table 1. Location, dimensions, and elevation of some selected outcrops of the MQD.

\begin{tabular}{ccccc}
\hline Samples & $\mathrm{N}$ & $\mathrm{E}$ & Remarks & Elevation \\
\hline QM-1 & 2931.680 & 3548.010 & $15 \mathrm{~m}$ wide, $5 \mathrm{~m}$ high, $300 \mathrm{~m}$ long & $869 \mathrm{~m}$ \\
QM-2 & 2929.534 & 3549.998 & $5 \mathrm{~m}$ wide, $2 \mathrm{~m}$ high, $14 \mathrm{~m}$ long & $889 \mathrm{~m}$ \\
QM-3 & 2928.982 & 3550.503 & $20 \mathrm{~m}$ wide, $30 \mathrm{~m}$ high, $100 \mathrm{~m}$ long & $858 \mathrm{~m}$ \\
QM-4 & 2928.033 & 3551.388 & $20-30 \mathrm{~m}$ wide, $50 \mathrm{~m}$ high, $100 \mathrm{~m}$ long & $852 \mathrm{~m}$ \\
\hline
\end{tabular}


gated and oval in shape and filled sometimes with either calcite or silica. Clustered vesicles up to $2 \mathrm{~cm}$ in size are present. Exfoliation of basalt boulders up to $5 \mathrm{~m}$ in diameter is common.

The MQD Megascopic study indicates that the basalt is fine to medium-grained, porphyritic and amygdaloidal. Dolerite is noticed in one locality which is composed of olivine phenocyrsts up to $0.5 \mathrm{~cm}$ in diameter. Plagioclase, pyroxene, olivine among other minerals are the essential minerals of the dike. Field studies show that the MQD hosts wide spectrum of upper crust inclusions with different diameters including different types of sandstone and limestone, phosphatic sandstone, quartzite and marble representing the stratigraphic column in the study area. The MQD intruded paleozoic and cretaceous sedimentary rocks as subvertical basaltic plugs (Figure 3). Granitic xenoliths were noticed in one locality. Similar inclusions have been identified by Abed et al. [21] in Jabal Aritain volcano at northeast Jordan, and by Al Malabeh [22], and Nasir and Al Fugha [23].

\subsection{Petrography of Basaltic Rocks}

The petrographical study of the basaltic rocks within MQD typically shows phyric, porphyritic, vitrophyric and locally glomerophyritic textures that dominated mainly by plagioclase and clinopyroxene and rare olivine and set in a matrix of plagioclase, pyroxene, brown glass and opaque phases (Figure 4). Few samples (such as QD-3) are non porphyritic, holocrystalline fine-grained basalt with almost no vesicles (Figure 4(c) and Figure 4(d)). The phenocryts of the basaltic lava are made up of $\sim 40 \%-50 \%$ plagioclase, $\sim 35 \%-40 \%$ clinopyroxene, with subordinate $\sim 5$ vol. $\%$ olivine, and opaques $\sim 5 \%-7 \%$. Clinopyroxene predominates over olivine. Microphenocyrsts of accessory phases including apatite are present in few samples. The microcrystalline groundmass of these
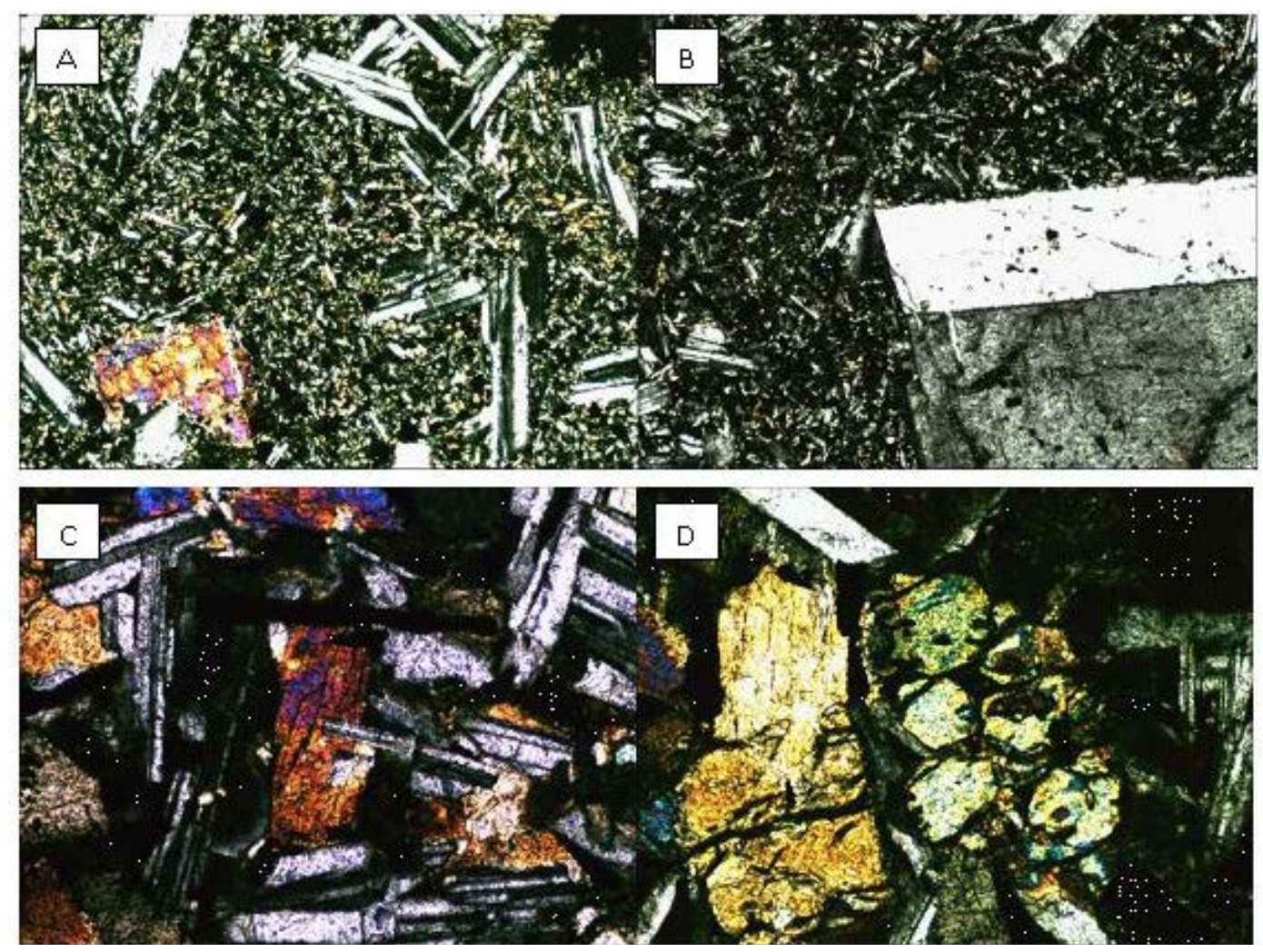

Figure 4. Photomicrographs of QMD basalt showing different textures: (A) Porphyritic and glomeropophyritic textures with plagioclase and clinopyroxene (at the left bottom) phenocrysts, and groundmass of plagioclase, pyroxene and opaques, $(20 \times)$, (XPL); (B) Porphyritic texture with medium size twinned plagioclase phenocryst with inclusions, $(50 \times)$, (XPL). Sample QD-2; (C) Subophitic texture of pyroxene oikocryst intruded by plagioclase. Iron oxides occur as elongated anhedral crystal that crosscut pyroxene and plagioclase, $(100 \times)$, (XPL). Sample QD-3; (D) Partly altered olivine crystal. Olivine is fractured and corroded. Iron oxides and opaques fill interstitial between crystals and they crosscut olivine and pyroxene (to the left), (100×), (XPL). Sample QD-3. 
basalts displays intergranular and seriate textures with a pilotaxitic texture which is mainly represented by acicular plagioclase laths, prismatic to anhedral pyroxene crystals, and some intergranular glass and magnetite (opaque) phases.

Plagioclase crystals are the predominant phase forming more than $45 \%$ of the basaltic phenocyrsts and microphenocyrsts. They occur in variety of forms and sizes, including subhedral to euhedral in shape and ranges in sizes from medium to fine phenocyrsts and to very fine acicular to needle microlites in the groundmass (Figure 4). Most of plagioclase phenocyrsts are twinned but rarely shows simple normal zoning. Plagioclase phenocyrsts are mostly clear in plane polarized light and not weathered but the coarse grains contains opaques and fluid inclusions (Figure 4). Some of the plagioclase occurs sub-ophitically enclosed in clinopyroxene crystal. Some of the plagioclase needles show slight alignment, possible lithophysae arranged in clots as glomeroporpyritic clusters. In few samples (e.g. sample QD-2), plagioclase laths and microlites exhibit flow texture. The later could indicate low viscosity nature of this basaltic magma, where the high hetereogenetic nucleationed plagioclase crystals were kept in suspension during lava consolidation.

Clinopyroxene (cpx) is the second dominant phase with concentrations of about $30 \%-35 \%$ that are generally represented by subhedral to anhedral forms of dusty beige to pale brown (probably Ti-rich) phenocryts. Most of the pyroxene crystals are corroded and superimposed by either plagioclase or replaced at the rims by Fe-Ti oxides. Some pyroxene is twinned. Finer size of the clinopyroxene crystals are confided to the groundmass. Very few pyroxene crystals show ophitic texture but mostly they are sub-ophitic with plagioclase.

Olivine (up to 5\%) is anhedral to subhedral. It occurs mainly as micro-phenocryts that are slightly altered to iddingsite and chlorite in both rims. Some of the olivine crystals are replaced by dark yellowish brown mineral that could be saponite or iddingsite. Clinopyroxene and olivine phenocyrsts show disequilibrium textures such as reaction/resorbed rims in the forms of corroded ends.

The paragenetic sequence shows that olivine was the first phase to be crystallized and coexist with pyroxene at sometime, while pyroxene continues crystallization. Plagioclase might have crystallized in contemporaneous and later than the pyroxene. The ophitic and supophitic textures of plagioclase and pyroxene point to near-equilibrium conditions of coexisting plagioclase and pyroxene phases close and beyond cotectic crystallization point, under more static conditions of the magmatic melt. Some of plagioclase phenocryts cross cut both clinopyroxene and olivine rims which indicate that plagioclase continue crystallizing after olivine and pyroxene.

The accessory phases are mainly magnetite, ilmenite (Fe-Ti oxide), and $+/-$ apatite and rarely spinel. They mainly occur as subhedral grains, although some of the fine iron oxides are elongated and filling intersertal spaces between phases. They may exhibit dendritic shapes (Figure 4 and Figure 5). These accessory phases are also occur as minute inclusions within pyroxene and plagioclase.

Glass mainly yellowish-brown in color, is interspersed among the microcrystalline grains as a result of incomplete crystallization. They usually show a hyalopilitic texture, although the glass is usually replaced. Calcite amygdules are slightly common in the samples. The outer rind of some of glassy is a few millimeters thick and was produced by quenching of the hot magma against cold surface. Few are embedded sparse phenocyrsts of FeTi oxide and $+/-$ olivine that crystallized before extrusion on the surface. Few vesicles were observed and were partly filled by very fine cryptocrystalline secondary silica and rimmed by dark opaque Fe-Ti oxides. Vesicles increases within the more porphyritc basalt.

A few possible lithophysae inclusions of high silica content were noticed. One grain is $\sim 7 \mathrm{~mm}$ in length and is angular. It is composed of very fine matrix of amorphous silica that includes coarser quartz grains $(\sim 1 \mathrm{~mm})$ of rounded to semi-rounded in shape. This litho fragment is highly fractured. They are surrounded by feathery rim crystals of cryptocrystalline clinopyroxene and iron oxides that are apparently nucleated heterogeneously around the inclusion as the result of its reaction with the silica under saturated melt, during the rapid quenching and substantial under cooling of the melt (Figure 5).

Porphyritic textures observed among the sections represent polygenetic of these basaltic rocks that probably involves a multi-stage cooling history for the melt. The presence of a variety of plagioclase shapes and sizes may indicate different stages in the cooling history but rather more likely to be affected by the sudden changes in the degree of super cooling $(\Delta \mathrm{T})$ or in the number of nuclei [24].

\subsection{Petrography and Mineralogy of Sedimentary Inclusions}

Inclusions from different rock types are present. Some evidences of heating of these inclusions were observed. 

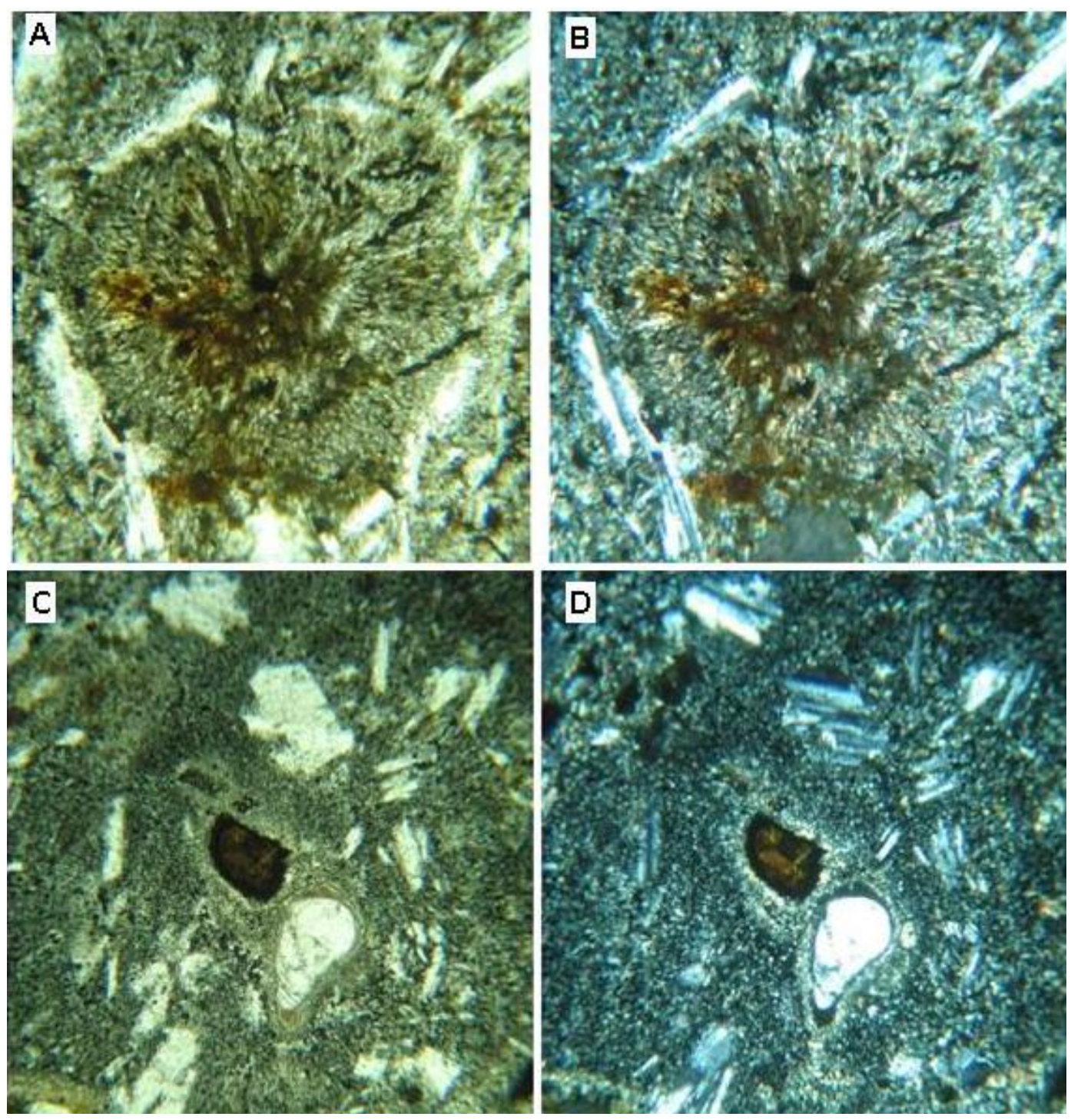

Figure 5. Photomicrographs of inclusions in the QMD basalt showing different textures: (A) Limestone inclusion surrounded by reaction rim of minute rod and feathery shaped very fine-grained minerals, PPL, mag. 100×; (B) Shows the same view, XPL, mag. 100×; (C) Quartz and iron oxides inclusions surrounded by reaction rims of very fine-grained minerals, PPL, mag. 100×; (D) Shows the same view, XPL, mag. 100×.

They are subjected to alteration by annealing. The inclusions as they transported to the surface by basaltic melt, they have been heated and altered in different ways. The presence of these inclusions gives some evidence of the composition of the crust below the MQD.

Sandstone and Quartzite inclusions are composed of fine- to medium-grained, poorly sorted, rounded to sub-rounded highly fractured quartz grains embedded in clay matrix. Sometimes clay minerals are laminated. In some cases, the matrix which supported the grains is made of microcrystalline calcite. Opaque minerals occur as black spots in some places. Ferruginous sandstone is with abundant iron oxide/hydroxide is also present.

Marble is made of recrystallized spary calcite with well developed druzy and mosaic texture. Calcareous phosphatic quartzite inclusions exhibit fine-grained, rounded, well sorted and fractured quartz grains. The major constituents are shell fragments, phosphatic pellets and apatite. Phosphatic limestone inclusions with packstone texture where calcite forms about $30 \%$. They are composed of black color phosphatic pellets due to heating, partially silicified, intraclasts of micrite, shells, bone fragments that are made up of cellophane (isotropic phosphate). 
Micro-granite inclusions are characterized by presence of quartz, orthoclase, plagioclase and biotite that are highly weathered to sericite. Secondary calcite fills the spaces between grains and cavities.

\subsection{Geochemistry}

The results of major and trace element chemistry of volcanic rocks and inclusions is listed in Table 2. The MQD rocks exhibit a narrow range of silica saturation between $(48.92-51.78 \mathrm{wt} \%)$ and can be classified as basalt using the Total Alkalis-Silica classification scheme [25] (Figure 6). The samples are subalkaline according to the alkaline-subalkaline classification system of MacDonald [26]. Figure 6 indicates that the MQD samples are unique in their total alkalis and silica composition if compared with Harrat Ash Shaam volcanic field in Jordan and rock suites from the intraplate volcanic fields in Saudi Arabia (Figure 6) [5] [27]-[29]. The MQD samples are subalkaline and lack more evolved compositions. As shown in Figure 6, it can be noticed that some samples of the Qitar El Abed dike are similar in composition to the MQD samples. Although the former is characterized by wider range of $\mathrm{SiO}_{2}$ content occupies fields of basalt, hawaiite and basanite [17]. The subalkaline affinities of the MQD samples with high silica and low alkaline content if compared with large intraplate basaltic fields in Jordan and Saudi Arabia is most probably attributed to presence of abundant silisiclastic inclusions in the MQD assimilated by the ascending magma. This can be concluded from the high silica content of the crustal inclusions as shown in Table 2.

$\mathrm{Al}_{2} \mathrm{O}_{3}$ contents in the MQD samples vary from 12.23 to $14.93 \mathrm{wt} \%$, meanwhile $\mathrm{CaO}$ varies between 6.82 and $9.05 \mathrm{wt} \%$. Figure 7 is a binary plot of $\mathrm{SiO}_{2}$ versus $\mathrm{Al}_{2} \mathrm{O}_{3}$ and $\mathrm{CaO}$. It exhibits the inverse relationships between both oxides and $\mathrm{SiO}_{2}$. $\mathrm{MgO}$ contents vary in the MQD from 9.79 to $5.51 \mathrm{wt} \%$, whereas $\mathrm{FeO}$ varies from 8.90 to 10.3 wt. $\%$. The Mg\# of the data set varies between $44.11 \%$ and $57.83 \%$ with an average of $49.83 \%$. Mg\# indicates the level of evolution of basalt since leaving the mantle. Mg\# of primitive basalt which originates in the mantle is $\sim 70$. As the basalt undergoes evolution while passing through crust and interacting with and assimilating other rock types in the crust, the Mg\# goes down from primitive number 70. Therefore, the Mg\# of the MQD indicates evolved to moderately evolved basalt. As shown in Figure 8, $\mathrm{Mg} \#$ decrease with increasing $\mathrm{SiO}_{2}$. $\mathrm{This}$ general trend suggests that fractional crystallization probably plays a role in decreasing Mg-number as a function of increasing $\mathrm{SiO}_{2}$ [29]. The general trends displayed by the binary variation diagrams (Figure 7 and Figure 8) indicate fractionation of olivine and clinopyroxene has taken place, although fractionation of these phases alone cannot be responsible for all the major element variation. The significant variation in major elements may suggests that factors such as a heterogeneous mantle source, variable degrees and depths of partial melting must be responsible for the major element variation.

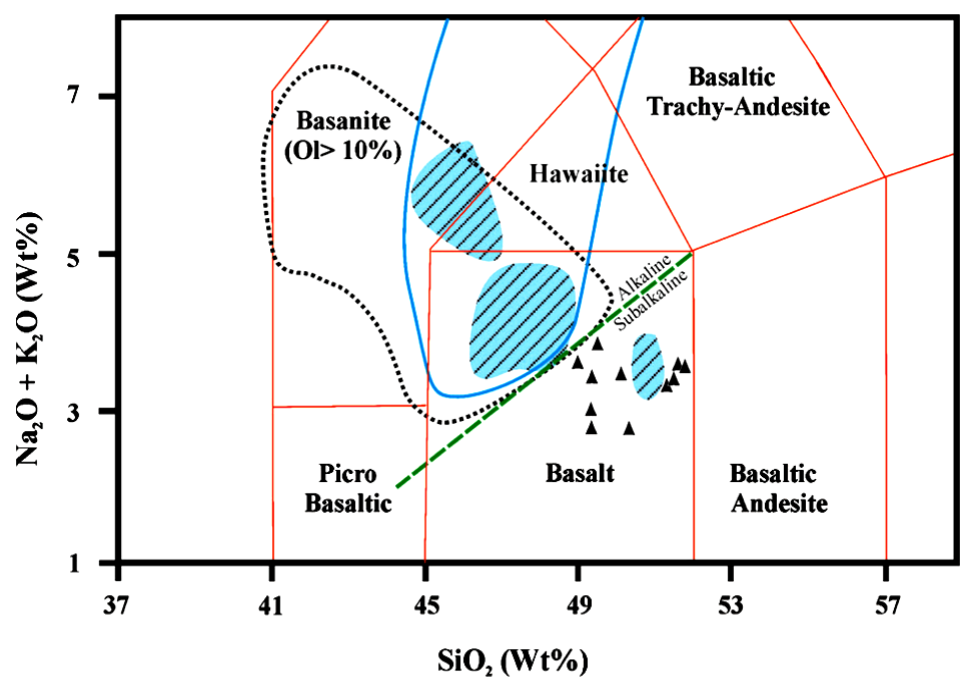

Figure 6. Total alkalis-silica diagram. Comparisons with Harrat Ash Shaam volcanic field in NE Jordan (dotted line), intraplate volcanic rocks from Saudi Arabia (solid line) and Qitar El Abed dike (hashered area). The alkaline-subalkaline divide is from MacDonald (1968). 
H. Alnawafleh et al.

Table 2. The QMD major oxides and trace elements chemistry results. (Samples with star are sedimentary inclusions).

\begin{tabular}{|c|c|c|c|c|c|c|c|c|c|c|c|c|c|c|}
\hline & BD1 & BD2 & BD3 & BD4 & BD5 & BD6 & BD7 & BD8 & BD9 & BD10 & BD12 & $\mathrm{DX} 2 *$ & DX3* & DX5* \\
\hline \multicolumn{15}{|c|}{ Oxides \% } \\
\hline $\mathrm{SiO}_{2}$ & 49.28 & 49.32 & 50.30 & 51.48 & 49.30 & 48.92 & 49.44 & 51.78 & 51.28 & 51.59 & 50.09 & 67.90 & 76.30 & 73.00 \\
\hline $\mathrm{TiO}_{2}$ & 2.42 & 2.83 & 2.74 & 2.95 & 2.56 & 3.37 & 3.36 & 2.92 & 2.93 & 2.90 & 3.20 & 2.00 & 1.00 & 0.90 \\
\hline $\mathrm{Al}_{2} \mathrm{O}_{3}$ & 13.46 & 12.80 & 12.90 & 12.80 & 13.20 & 14.93 & 14.40 & 12.23 & 12.63 & 12.82 & 14.11 & 12.50 & 8.60 & 10.60 \\
\hline $\mathrm{Fe}_{2} \mathrm{O}_{3}$ & 2.45 & 2.80 & 2.80 & 3.50 & 2.80 & 3.45 & 2.60 & 2.30 & 4.23 & 3.44 & 2.22 & 7.30 & 5.10 & 4.90 \\
\hline $\mathrm{FeO}$ & 9.34 & 9.87 & 9.68 & 8.90 & 9.87 & 10.23 & 8.96 & 10.30 & 8.90 & 9.23 & 10.23 & 1.23 & 2.23 & 2.12 \\
\hline $\mathrm{MnO}$ & 0.18 & 0.23 & 0.17 & 0.21 & 0.18 & 0.22 & 0.17 & 0.22 & 0.22 & 0.20 & 0.16 & 0.05 & 0.06 & 0.07 \\
\hline $\mathrm{MgO}$ & 6.96 & 7.56 & 6.97 & 6.39 & 8.79 & 6.48 & 5.96 & 5.88 & 5.51 & 6.60 & 7.90 & 0.90 & 1.70 & 2.10 \\
\hline $\mathrm{CaO}$ & 9.05 & 7.87 & 8.88 & 6.82 & 7.81 & 7.93 & 7.65 & 7.47 & 7.10 & 7.20 & 7.60 & 1.10 & 1.50 & 1.30 \\
\hline $\mathrm{Na}_{2} \mathrm{O}$ & 2.34 & 2.88 & 2.12 & 2.75 & 2.23 & 2.88 & 3.12 & 2.81 & 2.77 & 3.12 & 2.89 & 1.20 & 2.10 & 1.70 \\
\hline $\mathrm{K}_{2} \mathrm{O}$ & 0.59 & 0.48 & 0.55 & 0.59 & 0.48 & 0.67 & 0.68 & 0.69 & 0.48 & 0.40 & 0.50 & 0.70 & 0.80 & 1.90 \\
\hline $\mathrm{P}_{2} \mathrm{O}_{5}$ & 0.50 & 0.53 & 0.54 & 0.53 & 0.74 & 0.59 & 0.59 & 0.82 & 0.78 & 0.75 & 0.58 & 0.11 & 0.12 & 0.15 \\
\hline $\mathrm{SO}_{3}$ & 0.35 & 0.45 & 0.35 & 0.54 & 0.33 & 0.54 & 0.65 & 0.54 & 0.55 & 0.56 & 0.65 & 0.68 & 0.66 & 0.58 \\
\hline LOI & 2.10 & 1.50 & 0.90 & 2.00 & 0.90 & 0.20 & 1.90 & 1.60 & 1.80 & 1.10 & 0.50 & 3.60 & 0.50 & 1.00 \\
\hline Total & 99.02 & 99.12 & 98.90 & 99.46 & 99.19 & 100.41 & 99.48 & 99.56 & 99.18 & 99.91 & 100.63 & 99.27 & 100.67 & 100.32 \\
\hline Mg\# & 50.74 & 51.43 & 49.88 & 49.81 & 57.83 & 46.68 & 47.90 & 44.11 & 46.11 & 49.71 & 51.63 & & & \\
\hline \multicolumn{15}{|c|}{ Trace element (ppm) } \\
\hline $\mathrm{Ni}$ & 91 & 88 & 98 & 100 & 87 & 101 & 96 & 96 & 97 & 86 & 86 & 60 & 51 & 70 \\
\hline $\mathrm{Cr}$ & 110 & 112 & 127 & 115 & 110 & 115 & 129 & 118 & 120 & 130 & 110 & 91 & 71 & 91 \\
\hline $\mathrm{V}$ & 94 & 120 & 130 & 99 & 135 & 128 & 129 & 100 & 113 & 114 & 147 & 45 & 4 & 9 \\
\hline $\mathrm{Cu}$ & 50 & 79 & 780 & 1589 & 650 & 780 & 188 & 1069 & 1145 & 2600 & 83 & 1053 & 236 & 298 \\
\hline $\mathrm{Zn}$ & 91 & 160 & 166 & 174 & 187 & 153 & 125 & 157 & 163 & 209 & 117 & 67 & 17 & 48 \\
\hline $\mathrm{Pb}$ & 15 & 44 & 54 & 124 & 121 & 61 & 26 & 80 & 99 & 178 & 13 & 95 & 20 & 39 \\
\hline $\mathrm{Sr}$ & 450 & 480 & 470 & 441 & 486 & 517 & 468 & 459 & 439 & 472 & 499 & 230 & 351 & 160 \\
\hline $\mathrm{Ba}$ & 12 & 22 & 43 & 17 & 55 & 15 & 5 & 50 & 14 & 126 & 39 & 23 & 371 & 56 \\
\hline $\mathrm{Zr}$ & 500 & 411 & 434 & 436 & 543 & 542 & 578 & 428 & 429 & 409 & 391 & 612 & 556 & 568 \\
\hline $\mathrm{Nb}$ & 18 & 23 & 25 & 27 & 27 & 29 & 27 & 25 & 27 & 24 & 20 & 30 & 18 & 22 \\
\hline $\mathrm{Y}$ & 22 & 25 & 22 & 24 & 23 & 27 & 26 & 25 & 26 & 24 & 24 & 22 & 27 & 24 \\
\hline $\mathrm{La}$ & 21 & 27 & 23 & 27 & 28 & 27 & 25 & 28 & 26 & 24 & 21 & 42 & 56 & 38 \\
\hline $\mathrm{Ce}$ & 35 & 26 & 30 & 40 & 32 & 33 & 37 & 36 & 42 & 32 & 27 & 79 & 89 & 79 \\
\hline Co & 37 & 26 & 27 & 30 & 29 & 34 & 29 & 28 & 31 & 24 & 28 & 22 & 5 & 32 \\
\hline $\mathrm{Li}$ & 51 & 25 & 34 & 15 & 24 & 17 & 34 & 16 & 17 & 36 & 16 & 15 & 14 & 6 \\
\hline $\mathrm{Be}$ & 10 & 11 & 21 & 11 & 31 & 14 & 15 & 17 & 10 & 13 & 15 & 4 & 2 & 2 \\
\hline As & 40 & 123 & 154 & 117 & 89 & 64 & 96 & 95 & 119 & 73 & 49 & 46 & 44 & 57 \\
\hline $\mathrm{Sn}$ & 8 & 29 & 76 & 91 & 65 & 37 & 55 & 43 & 53 & 144 & 77 & 65 & 17 & 21 \\
\hline W & 3 & 4 & 3 & 6 & 5 & 4 & 1 & 5 & 2 & 4 & 2 & 6 & 5 & 5 \\
\hline
\end{tabular}




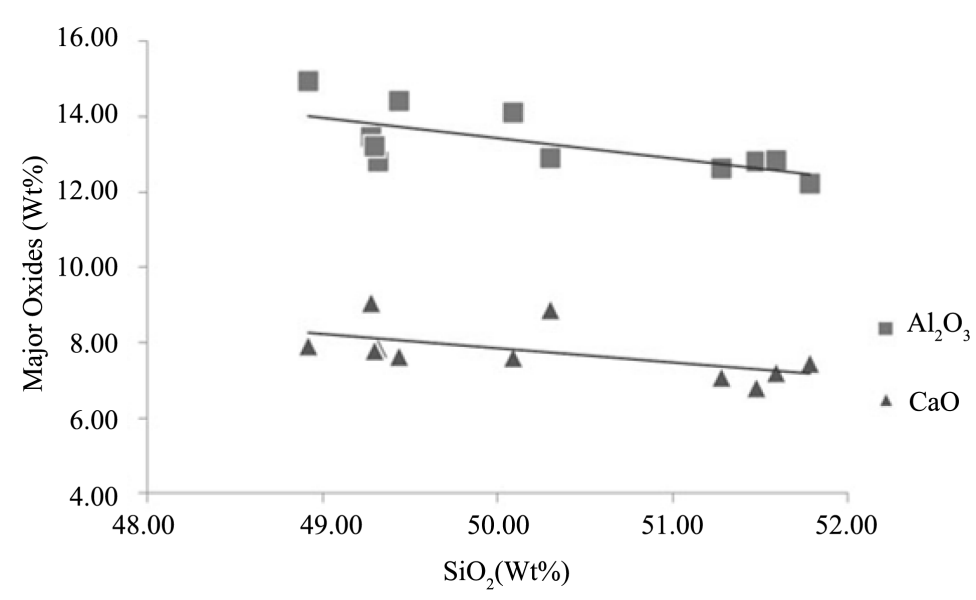

Figure 7. $\mathrm{SiO}_{2}$ vs. $\mathrm{CaO}$ and $\mathrm{Al}_{2} \mathrm{O}_{3}$ data.

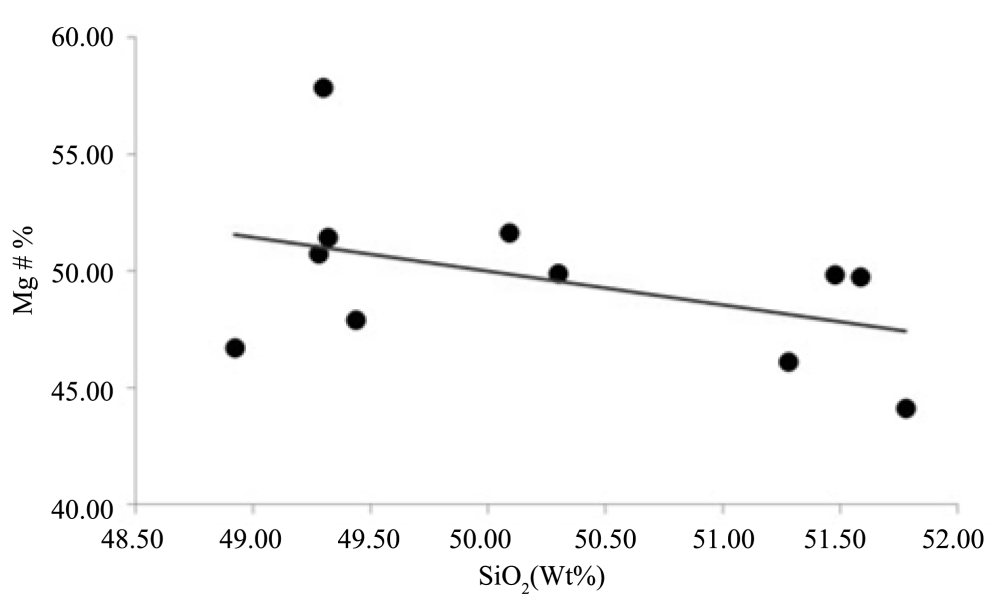

Figure 8. $\mathrm{SiO}_{2}$ vs $\mathrm{Mg} \#$ data.

In the binary diagram (Figure 9), the $\mathrm{Mg} \#$ is plotted versus $\mathrm{Ni}$ and $\mathrm{Cr}$. The general trend is decrease of $\mathrm{Ni}$ and

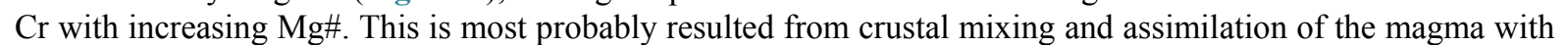
the country rock which resulted to dilution of $\mathrm{Ni}$ and $\mathrm{Cr}$, where $\mathrm{Cr}$ is related to clinopyroxene [30].

The primitive mantle normalized trace elements is shown in Figure 10 (normalization values from Sun and McDonough [31]). It is quite obvious from the diagram that trace elements are enrich in factor of 10 to 100 except to $\mathrm{W}, \mathrm{Pb}$ and $\mathrm{Sn}$ which are enriched 177, 400 and 363 respectively. This enrichment is might be due to crustal contamination during magma ascending.

\subsection{Origin}

Early Miocene NW-SE dikes are well known from Jordan [16] [17] [32] [33], central Sinai [18] and in the Red Sea region (Baldridge et al., 1991). According to Baldridge et al. [34], the great $100 \mathrm{~km}$-wide dike swarm which runs the length of the Red Sea gave ages of 26 - $18 \mathrm{Ma}$. Sebai et al. [13] and Burke [35] suggest that these dikes are controlled by major NW-SE trend fault systems, which trend in the same direction as the fault systems of the Red Sea. Field evidences in the study area of the MQD indicate presence of a regional NW-SE fault system exploited by the magma during the Early Miocene to erupt through this fault system. According to Burke [35] and Chazot et al. [36], this phase is probably the peripheral extension of a large magmatic event widely exposed in the realm of the Red Sea and referred to as syn-rift volcanism. It is said by Burke [35] that this syn-rift volcanism is characterized by a tholeiitic basalt composition, which is related to the formation of an intra-continental rift that forms the site on which the Red Sea is now developing [11] [35] and accompanied the early opening of the Red Sea rift [3] [13] [27]. Early Miocene volcanism in Jordan is consistent with a model of lithosphere 

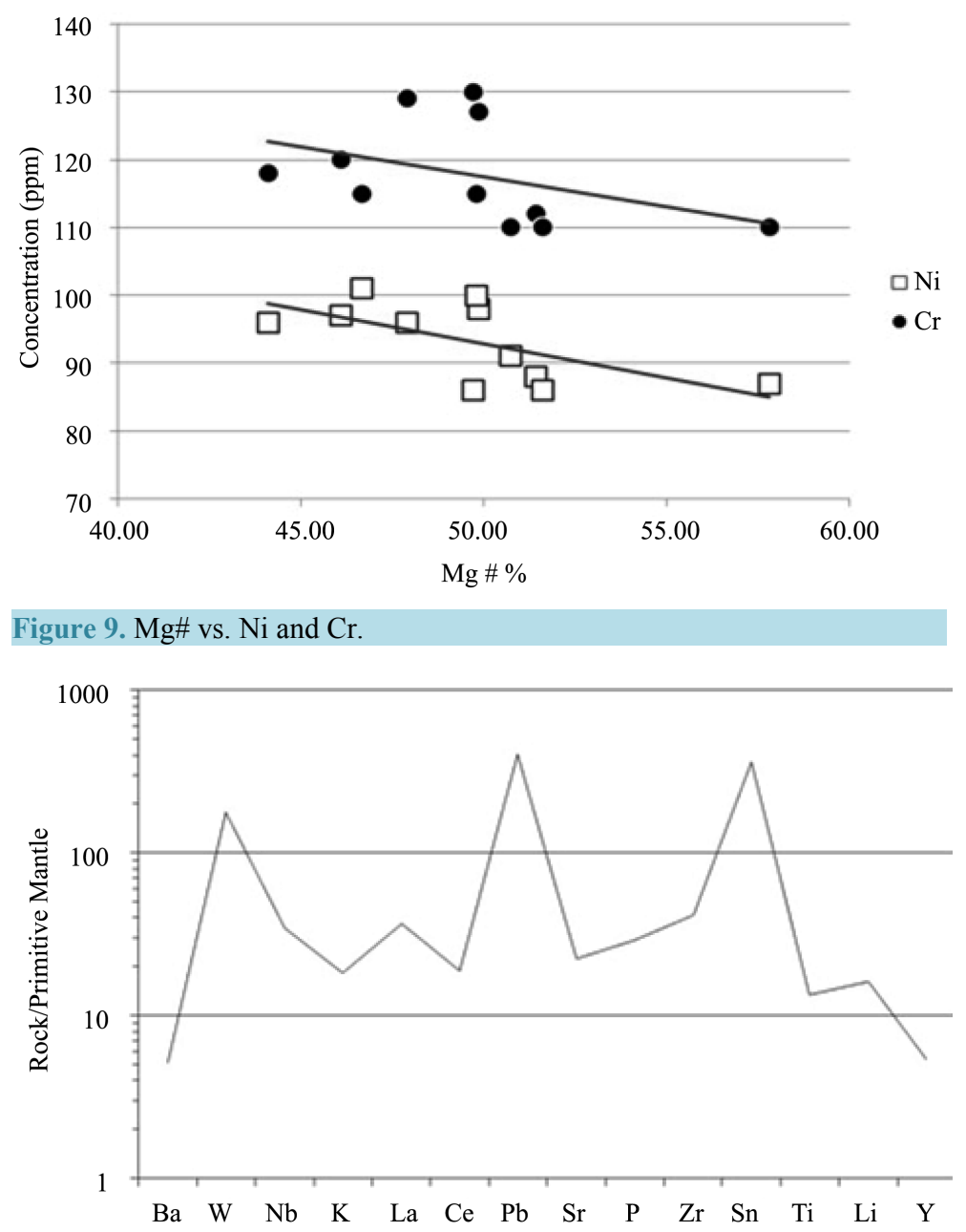

Figure 10. Primitive mantle normalized multi-elements spider diagrams. Normalization values from Sun \& McDonough (1989).

extension controlled melting where there was dominated by lithospheric trace element/isotopic signatures [38]. Accordingly, a mantle plume is not required for melt generation. Shaw [29] concluded that the Afar plume has not been channeled northwards beneath the Arabian plate and plays no role in Jordan intraplate volcanic fields including MQB. The unique petrographical and geochemical affinities of the MQD are related to presence of abundant sedimentary inclusions which are partially assimilated by the ascending magma and lead to crustal contamination.

\section{Conclusions}

The NW-SE trending Mudawwara-Quwayra Dike (MQD) is a very important dike in terms of volcano-tectonic evolution of the south Jordan. The MQD is controlled by a major NW-SE trend fault system. They volcanic activity which is related to eruption of the MQD is attributed to regional phase of magmatism in Jordan and Saudi Arabia. This phase is probably the peripheral extension of a large magmatic event widely exposed in the Red Sea realm.

The MQD intruded Paleozoic and Cretaceous sedimentary rocks as sub-vertical basaltic plugs, extending for more than $100 \mathrm{~km}$. This dike forms positive irregularly features and is represented by symmetrical, elliptical, elongated or circular domes and hills up to $20 \mathrm{~m}$ high, $150 \mathrm{~m}$ length and $100 \mathrm{~m}$ wide. Field evidences indicate the presence of thin basaltic layers intercalated with pyroclastic materials, volcanic bombs and inclusions of different size and lithology, including limestone, sandstone, phosphate, quartzite, and marble. 
The petrographical and geochemical affinities of the MQD are unique if compared with intraplate basalts of Jordan and Saudi Arabia. The MQD is sublkaline basalt with high silica content and low alkalis. The unique petrographical and geochemical affinities of the MQD are most probably related to presence of abundant sedimentary inclusions which are partially assimilated by the ascending magma.

\section{References}

[1] Tarawneh, K. (1999) Geological Map of Wadi Al Abid Area (Map Sheet No. 3454-I). National 1:50,000 Mapping Project, NRA, Geol. Dir., Map. Div., Amman.

[2] Tarawneh, K. (2000) The Geology of Wadi Al Abid Area (Map Sheet No. 3454I). Scale 1:50,000. NRA, Geol. Dir., Map. Div., Bulletin, Vol. 44, 39 p.

[3] Tarawneh, K., Ibrahim, K. and Rabba, I. (2002) Petrography, Geochemistry and K-Ar Geochronology of the Dike Systems NW-SE of the Harrat Ash Shaam in NE Jordan. Mutah Lil Buhuth wad Dirasat. Natural and Applied Series, 17, 69-87.

[4] Ibrahim, K., Tarawneh, K. and Rabba, I. (2003) Phases of Activity and Geochemistry of Basaltic Dike Systems in Northeast Jordan Parallel to the Red Sea. Journal of Asian Earth Science, 21, 467-472. http://dx.doi.org/10.1016/S1367-9120(02)00075-5

[5] Camp, V.E. and Rooble, M.J. (1992) Upwelling Asthenosphere beneath Western Arabia and Its Regional Implications. Journal of Geophysical Research, 97, 15 p. http://dx.doi.org/10.1029/92JB00943

[6] Camp, V.E., Rooble, M.J. and Hooper, P.R. (1991) The Arabian Continental Alkali Basalt Province: Part II. Evolution of Harrats Khaybar, Ithnayn, and Kura, Kingdom of Saudi Arabia. Geological Society of America Bulletin, 103, 363-391. http://dx.doi.org/10.1130/0016-7606(1991)103<0363:TACABP >2.3.CO;2

[7] Coleman, R.C. (1993) Geologic Evolution of the Red Sea, Oxford Monograph Geological Geophysics. Oxford University Press, New York, Vol. 24, 186.

[8] Guba, I. and Mustafa, H. (1988) Structural Control of Young Basaltic Fissure Eruptions in the Plateau Basalt Area of the Arabian Plate, NE Jordan. Journal of Volcanology and Geothermal Research, 35, 319-334. http://dx.doi.org/10.1016/0377-0273(88)90026-1

[9] Ibrahim, K. (1993) The Geological Framework for the Harrat Ash Shaam Basaltic Super-Group and Its Volcanic Evolution. NRA, Geological Directorate, Mapping Division, Bulletin, Vol. 25, 33 p.

[10] Ibrahim, K., Shaw, J., Baker, J., Khouri, H., Rabba, I. and Tarawneh, K. (2006) Pliocene-Pleistocene Volcanism in North-Western Arabian Plate (Jordan): I. Geology and Geochemistry of the Asfar Volcanic Group. Journal of Neues Jahrbuch fur Geologie und Palaontologie, 2-3, 145-170.

[11] Ilani, S., Harlavan, Y., Tarawneh, K., Rabba, I., Weinberger, R., Ibrahim, K., Peltz, S. and Steinitz, G. (2001) New K-Ar Ages of Basalts from the Harrat Ash Shaam Volcanic Field in Jordan: Implications for the Span and Duration of the Upper Mantle Upwelling beneath the Western Arabian Plate. Geology, 29, 171-174. http://dx.doi.org/10.1130/0091-7613(2001)029<0171:NKAAOB $>2.0 . C O ; 2$

[12] Moffat, D.T. (1989) A Volcanotectonic Analysis of the Cenozoic Continental Basalts of Northern Jordan; Implications for Hydrocarbon Prospecting in the Block B Area. ERI Jordan EJ88-1, 73 p.

Nasir, S. and Al Fuqha, H. (1988) Spinel-Lherzolite Xenoliths from Aritayn Volcano, NE Jordan. Mineralogy and Petrography, 38, 127-143. http://dx.doi.org/10.1007/BF01164317

[13] Sebai, A., Zumbo, V., Feraud, G., Bertrand, H., Hussain, A., Giannerini, G. and Camperdon, R. (1991) 40Ar/39Ar Dating of Alkaline and Tholeiitic Magmatism of Saudi Arabia Related to the Early Red Sea Rifting. Earth and Planetary Letters, 104, 473-487. http://dx.doi.org/10.1016/0012-821X(91)90223-5

[14] Krienitz, M.S., Haase, K.M., Mezger, K., van den Bogaard, P., Thiemann, V. and Shaikh-Mashail, M.A. (2009) Tectonic Events, Continental Intraplate Volcanism, and Mantle Plume Activity in Northern Arabia: Constraints from Geochemistry and Ar-Ar Dating of Syrian Lavas. Geochemistry, Geophysics, Geosystems, 10, No. 4. http://dx.doi.org/10.1029/2008GC002254

[15] Shallaly, N.A., Beier, C., Haase, K.M. and Hammed, M.S. (2013) Petrology and Geochemistry of the Tertiary Suez Rift Volcanism, Sinai, Egypt. Journal of Volcanology and Geothermal Research, 267, 119-137. http://dx.doi.org/10.1016/j.jvolgeores.2013.10.005

[16] Barberi, F., Capaldi, G., Gasperini, P., Marinelli, G., Santacroce, R., Scandone, R., Treuil, M. and Varet, J. (1979) Recent Basaltic Volcanism of Jordan and Its Implications on the Geodynamic Evolution of the Afro-Arabian Rift System. Accademia Nazionale Dei Lincei, Atti Del Corvegni Lincei, Rome, 47, 667-683.

[17] Ibrahim, K.M., Tarawneh, K. and Rabba', I. (2003) Phases of Activity and Geochemistry of Basaltic Dike Systems in Northeast Jordan Parallel to the Red Sea. Journal of Asian Earth Science, 21, 467-472. 
http://dx.doi.org/10.1016/S1367-9120(02)00075-5

[18] Steinitz, G., Baratov, Y. and Hunziker, J.C. (1978) K-Ar Age Determinations of Some Miocene-Pliocene Basalts in Israel: Their Significance to the Tectonics of the Rift Valley. Geological Magazine, 115, 329-340. http://dx.doi.org/10.1017/S0016756800037341

[19] Hempton, M. (1987) Constraints on the Arabian Plate Motion and Extensional History of the Red Sea. Tectonics, 6, 687-705. http://dx.doi.org/10.1029/TC006i006p00687

[20] Abu Lihie, O. (1988) Geological Map of Jabal Ladghayn-Dubaydib Area. Map Sheet No. 3148 II-3148I. National 1:50,000 Mapping Project, Natural Resources Authority, Geology Directorate, Mapping Division, Amman.

[21] Abed, A., Khoury, H. and Kruhl, H. (1985) On the Structure of Jabal Aritain Volcano (NE Jordan) and Petrology of Some Xenoliths. Dirasat, 12, 109-124.

[22] Al-Malabeh, A. (1993) The Volcanology, Mineralogy, and Geochemistry of Selected Pyroclastic Cones from NE Jordan and Their Evaluation for Possible Industrial Applications. PhD Thesis, Universitat Erlangen, Nurnberg, $300 \mathrm{p}$.

[23] Nasir, S. and Al Fugha, H. (1988) Spinal Iherzolite Xenoliths from the Aritain Volcano. NE Jordan. Mineral and Petrology, 39, 127-137. http://dx.doi.org/10.1007/BF01164317

[24] Kystol, J. and Larsen, L.M. (1999) Analytical Procedures in the Rock Geochemical Laboratory of the Geological Survey of Denmark and Greenland. Geology of Greenland Survey Bulletin, 184, 56-62.

[25] Le Bas, M.J., Le Maitre, R.W., Streckeisen, A. and Zanettin, B. (1986) A Chemical Classification of Volcanic Rocks Based on the Total Alkalis-Silica Diagram. Journal of Petrology, 27, 745-750. http://dx.doi.org/10.1093/petrology/27.3.745

[26] MacDonald, G.A. (1986) Composition and Origin of Hawaiian Lavas. Meeting of Geological Society of America, 116, 477-522. http://dx.doi.org/10.1130/MEM116-p477

[27] Baker, J.A., Menzies, M.A., Thirlwall, M.F. and Macpherson, C.G. (1997) Petrogenesis of Quaternary Interpolate Volcanism, Sana'a, Yemen: Implication for Plume-Lithosphere Interaction and Polybaric Melt Hybridization. Journal of Petrology, 38, 1359-1390. http://dx.doi.org/10.1093/petroj/38.10.1359

[28] Saffarini, G., Nasir, S. and Abed, A. (1985) A Contribution on the Geochemistry of Quaternary Basalts in Central Jordan. Dirasat, 7, 133-143.

[29] Shaw, J. (2003) Geochemistry of Cenozoic Volcanism and Arabian Lithospheric Mantle in Jordan. Unpublished PhD Thesis, University of London, London.

[30] Wilson, M. (1989) Igneous Petrogenesis. A Global Tectonic Approach. Unwin Hyman, London, 466. http://dx.doi.org/10.1007/978-1-4020-6788-4

[31] Sun, S., and Mcdonough, W. (1989) Chemical and Isotopic Systematic of Oceanic Basalts: Implications for Mantel Composition and Processes. In: Saunders, A. and Norry, M., Eds., Magmatism in the Ocean Basins, Special Publication of geological Society of London, 42, 313-345. http://dx.doi.org/10.1144/GSL.SP.1989.042.01.19

[32] Bender, F. (1968) Geolgie von Jordanian. Beitrage zur regionlen Geologie der Erde. Borntrager, Berlin-Stuttgart, 230 p.

[33] Bender, F. (1974) Geology of Jordan. Borntraeger, Berlin, 196 p.

[34] Baldridge, W.S., Eyal, Y., Bartov, Y., Steinitz, G. and Eyal, M. (1991) Miocene Magmatism of Sinai Related to the Opening of the Red Sea. Tectonophysics, 197, 181-201. http://dx.doi.org/10.1016/0040-1951(91)90040-Y

[35] Burke, K. (1996) The African Plate. South African Journal of Geology, 99, 341-409.

[36] Chazot, G., Menzies, M.A. and Baker, J. (1998) Chapter B2: Pre-, Syn-, and Post-Rift Volcanism on the Southwestern Margin of the Arabian Plate. In: Purser, B.H. and Bosence, D.W.J., Eds., Sedimentation and Tectonics of Rift Basins: Red Sea-Gulf of Aden, Chapman \& Hall, London, 50-56. http://dx.doi.org/10.1007/978-94-011-4930-3_4

[37] Feraud, G., Zumbo, V. and Sebai, A. (1991) 40Ar/39Ar and Duration of Tholeiitic Magmatism Related to the Early Opening of the Red Sea Rift. Geophysical Research Letters, 18, 195-198. http://dx.doi.org/10.1029/91GL00207

[38] Shaw, J., Baker, J., Menzies, M., Thirlwall, M. and Ibrahim, K. (2003) Petrogenesis of Largest Interpolate Volcanic Field on the Arabian Plate (Jordan): A Mixed Lithosphere-Asthenosphere Source Activated by Lithospheric Extension. Journal of Petrology, 44, 1657-1679. http://dx.doi.org/10.1093/petrology/egg052 